\title{
Oligoarginine Peptide Conjugated to BSA Improves Cell Penetration of Gold Nanorods and Nanoprisms for Biomedical Applications
}

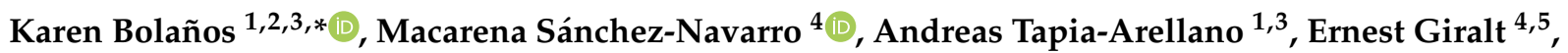 \\ Marcelo J. Kogan 1,3,*(D) and Eyleen Araya ${ }^{3,6, *}$
}

1 Departamento de Química Farmacológica y Toxicológica, Facultad de Ciencias Químicas y Farmacéuticas, Universidad de Chile, Santiago 8380494, Chile; atare_28@ciq.uchile.cl

2 Laboratorio de Comunicaciones Celulares, Centro de Estudios en Ejercicio, Metabolismo y Cancer (CEMC), Santiago 8380453, Chile

3 Advanced Center of Chronic Diseases (ACCDis), Santiago 8380494, Chile

4 Institute for Research in Biomedicine (IRB Barcelona), The Barcelona Institute of Science and Technology, Baldiri Reixac 10, 08028 Barcelona, Spain; macarena.sanchez@ipb.csic.es (M.S.-N.); ernest.giralt@irbbarcelona.org (E.G.)

5 Department of Inorganic and Organic Chemistry, University of Barcelona, Martí i Franquè s 1-11, 08028 Barcelona, Spain

6 Departamento de Ciencias Quimicas, Facultad de Ciencias Exactas, Universidad Andres Bello, Santiago 8370146, Chile

check for updates

Citation: Bolaños, K.; Sánchez-Navarro, M.; Tapia-Arellano, A.; Giralt, E.; Kogan, M.J.; Araya, E. Oligoarginine Peptide Conjugated to BSA Improves Cell Penetration of Gold Nanorods and Nanoprisms for Biomedical Applications. Pharmaceutics 2021, 13, 1204. https:// doi.org/10.3390/pharmaceutics13081204

Academic Editors: Marina

Santiago Franco and Yu-Seok Youn

Received: 2 July 2021

Accepted: 29 July 2021

Published: 5 August 2021

Publisher's Note: MDPI stays neutral with regard to jurisdictional claims in published maps and institutional affiliations.

Copyright: (c) 2021 by the authors. Licensee MDPI, Basel, Switzerland. This article is an open access article distributed under the terms and conditions of the Creative Commons Attribution (CC BY) license (https:/ / creativecommons.org/licenses/by/ $4.0 /)$.
* Correspondence: k.bolaosjimenez@uandresbello.edu (K.B.); mkogan@ciq.uchile.cl (M.J.K.); eyleen.araya@unab.cl (E.A.)

\begin{abstract}
Gold nanoparticles (AuNPs) have been shown to be outstanding tools for drug delivery and biomedical applications, mainly owing to their colloidal stability, surface chemistry, and photothermal properties. The biocompatibility and stability of nanoparticles can be improved by capping the nanoparticles with endogenous proteins, such as albumin. Notably, protein coating of nanoparticles can interfere with and decrease their cell penetration. Therefore, in the present study, we functionalized albumin with the $\mathrm{r}_{8}$ peptide (All-D, octaarginine) and used it for coating NIRplasmonic anisotropic gold nanoparticles. Gold nanoprisms (AuNPrs) and gold nanorods (AuNRs) were coated with bovine serum albumin (BSA) previously functionalized using a cell penetrating peptide (CPP) with the $r_{8}$ sequence (BSA- $r_{8}$ ). The effect of the coated and $r_{8}$-functionalized AuNPs on HeLa cell viability was assessed by the MTS assay, showing a low effect on cell viability after BSA coating. Moreover, the internalization of the nanostructures into HeLa cells was assessed by confocal microscopy and transmission electron microscopy (TEM). As a result, both nanoconstructs showed an improved internalization level after being capped with BSA- $\mathrm{r}_{8}$, in contrast to the BSA-functionalized control, suggesting the predominant role of CPP functionalization in cell internalization. Thus, our results validate both novel nanoconstructs as potential candidates to be coated by endogenous proteins and functionalized with a CPP to optimize cell internalization. In a further approach, coating AuNPs with CPP-functionalized BSA can broaden the possibilities for biomedical applications by combining their optical properties, biocompatibility, and cell-penetration abilities.
\end{abstract}

Keywords: cell internalization; albumin; BSA; CPP; gold nanorods; gold nanoprisms; arginine-rich peptide

\section{Introduction}

Research on nanomaterials has expanded in recent years for their use in drug delivery, imaging, therapy, diagnosis, and combined therapy, among other fields [1-5]. Organic, inorganic, biological-type, or hybrids between different structures have been proposed for diverse medical/biomedical applications [6-14]. Among the prospective materials for future applications, gold nanoparticles stand out, owing to their wide-ranging potential. 
AuNPs have characteristic optical properties that are derived from their localized surface plasmon resonance (LSPR), allowing them to interact with light in a different way than bulk materials do $[10,15,16]$. The plasmon excitation has two main decay mechanisms: radiative and non-radiative, resulting in light scattering and absorption, respectively [17]. Light scattering of AuNPs has been extensively used to design diagnostic tools, contrast agents, and Raman enhancement probes [18-20]. Conversely, absorption of light involves relaxation via electron-electron collisions or electron-lattice-phonon couplings, yielding light-to-heat conversion, [21] referred to as the photothermal effect, which can be used for drug release and photodynamic and photothermal therapy [22].

Both LSPR and the optical properties of AuNPs are highly shape- and size-dependent. In this regard, AuNRs and AuNPrs are two interesting AuNP geometries because their light absorption can be synthetically modulated. Therefore, their maximum absorption can be tuned to the biological window (the region that exhibits minimum light absorption of the biological tissues) [23-26], with a strong optical extinction and for photothermal applications $[17,27]$.

Given the wide range of applications for AuNPs as biomedical platforms, it is essential to consider the biocompatibility of this material. AuNPrs (synthesized by sodium thiosulfate reduction) have been shown to be non-cytotoxic $[28,29]$. In contrast, AuNRs are commonly synthesized using the CTAB surfactant, which has shown some cytotoxic effects [30-32].

In order to avoid possible cytotoxic effects from our nanocarriers, we incorporated a protein coating on both AuNPs to increase their biocompatibility and stability [6,29,33-36]. BSA shares $76 \%$ sequence identity with human serum albumin (HSA) [37] and is well tolerated by humans [38]. This protein has been extensively used for the development of nanomaterials for biomedical applications in drug delivery, therapy (photothermal or combined), diagnosis, and theranostics [39-45].

Even though the presence of proteins as a coating on the nanoparticle's surface improves their biocompatibility and stability properties, it may also limit their internalization capacity due to alterations of the protein corona composition and, consequently, the interaction with receptors and membranes [46-48]. In this regard, the possible biomedical applications of AuNPs can be expanded as their cell internalization ability is increased. Accordingly, arginine-rich CPPs, (minimum amount of six Arg) are well known for their ability to cross biological barriers $[49,50]$. Although other studies have reported the conjugation of nanoparticles with internalization peptides in a direct way [51-54], it is also well known that the presence of BSA improves the circulation time of nanoparticles and controls the composition of the protein corona in physiological media, hence the importance of the inclusion of albumin in nanoparticles $[37,55,56]$. Therefore, we functionalized the BSA protein with $r_{8}$ to facilitate cell penetration of the AuNPs. Previous studies have shown that the use of arginine-rich CPPs increases cell penetration of the nanocarriers, opening the possibility for the improved cell internalization of AuNPs [51,57-59]. In particular, $\mathrm{r}_{8}$ has been covalently linked to several molecules and nanosystems, such as insulin [60] liposomes, [61] quantum dots, [62] and gold nanorods, [49,58] improving their uptake and cell penetration in target sites. Nevertheless, coating AuNRs and AuNPrs (with absorption in the first biological window) with BSA, functionalized with $\mathrm{r}_{8}$ for cell internalization, has not been reported yet. In this study, we proposed that BSA- $r_{8}$ enhances the cell internalization of AuNPs, taking as examples two promissory anisotropic AuNPs with different surface and charge: AuNRs and AuNPrs, with absorption on the first biological window (650-950 nm) [63] for possible applications in biomedical nanoplatforms.

\section{Materials and Methods}

\subsection{Materials}

$\mathrm{HAuCl}_{4}$ (Gold (III) chloride hydrate), $\mathrm{Na}_{2} \mathrm{~S}_{2} \mathrm{O}_{3}$ (sodium thiosulfate), hexadecyltrimethylammonium bromide (CTAB), $\mathrm{NaBH}_{4}$, and $\mathrm{AgNO}_{3}$ were acquired from Sigma-Aldrich (St. Louis, MO, USA). Polyethylene Glycol 5 kDa (HS-PEG-COOH, 5 kDa) was from JenKem 
Technology (Beijing, China). Milli-Q water was obtained from the purification of distilled water with the Simplicity SIMS 00001 equipment (Millipore, Molsheim, France). Cell culture plates and flasks were from Corning Costar (Corning, NY, USA). Penicillin/streptomycin and chemicals for cell culture were from Gibco (Gibco-BRL, Paisley, UK), fetal bovine serum (FBS, Biological Industries, Cromwell, CT, USA). MTS/PMS [3-(4,5-dimethylthiazol-2-yl)-5(3-carboxymethoxyphenyl)-2-(4-sulfophenyl)-2H-tetrazolium, inner salt, MTS/phenazine methosulfate, PMS], and CellTiter 96 kit were from Promega (Promega, Madison, WI, USA). Atto-565 NHS ester (A565) was from Sigma (Sigma-Aldric Chemie, Buch, Switzerland). Other reagents were from Sigma-Aldrich.

\subsection{Experimental}

\subsubsection{AuNRs Synthesis}

AuNRs were synthesized using a previously reported seed-mediated procedure [64]. Briefly, $5 \mathrm{~mL}$ of a $0.3 \mathrm{mM} \mathrm{HAuCl}_{4}$ solution in CTAB $0.1 \mathrm{M}$ was reduced by ice-cold $\mathrm{NaBH}_{4}$ $10 \mathrm{mM}(300 \mu \mathrm{L})$, resulting in a brownish-yellow seed solution. Then, $10 \mathrm{~mL}$ of a $0.5 \mathrm{mM}$ $\mathrm{HAuCl}_{4}$ solution (in CTAB $0.1 \mathrm{M}$ ) was reduced by ascorbic acid in the presence of $\mathrm{AgNO}_{3}$, until it reached a colorless growth solution. Finally, $120 \mu \mathrm{L}$ of the seed solution was added to the growth solution and allowed to rest for $30 \mathrm{~min}$ in a thermostatic bath at $27^{\circ} \mathrm{C}$. The obtained AuNRs were centrifuged at $7030 \mathrm{~g}$ for $30 \mathrm{~min}$, and the pellet was resuspended in Milli-Q water.

\subsubsection{AuNPrs Synthesis}

AuNPrs were obtained by $\mathrm{Na}_{2} \mathrm{~S}_{2} \mathrm{O}_{3}$ reduction of $\mathrm{HAuCl}_{4}$, as previously reported [28,36]. A $2 \mathrm{mM} \mathrm{HAuCl}_{4}$ solution was first reduced by $0.6 \mathrm{mM} \mathrm{Na}_{2} \mathrm{~S}_{2} \mathrm{O}_{3}$ and allowed to rest for $9 \mathrm{~min}$. Then, a second addition of $0.6 \mathrm{mM} \mathrm{Na} \mathrm{S}_{2} \mathrm{O}_{3}$ was performed, and the solution was left undisturbed for $30 \mathrm{~min}$. The purple solution containing the AuNPs was centrifuged and resuspended in Milli-Q water. PEG functionalization was achieved at $\mathrm{pH}=12$ by adding $15 \mu \mathrm{L}$ of a $2.7 \mathrm{mM}$ HS-PEG5000-COOH solution and allowing conjugation under a magnetic stirrer for $3 \mathrm{~h}$. Finally, AuNPrs were separated from smaller undesired AuNPs using a successive differential centrifugation procedure, as reported [36].

\subsubsection{Characterization of the Nanoparticles}

AuNRs and AuNPrs were characterized before and after BSA-r $\mathrm{r}_{8}$ coating by UV-VisNIR absorption spectra, using a Lambda 25 spectrophotometer (Perkin Elmer, Waltham, MA, USA). Dynamic light scattering (DLS) and Z potential measurements were acquired in $\mathrm{PBS} \mathrm{pH}=7$, at $25^{\circ} \mathrm{C}$, using a Zetasizer 3000 (Malvern Instruments, Malvern, UK), as triplicates in aqueous solution at $25^{\circ} \mathrm{C}$.

TEM images of AuNRs were acquired with a JEOL JEM-1010 microscope (JEOL USA, Peabody, MA, USA), using Formvar carbon-coated copper microgrids (200 mesh; Ted Pella, Redding, CA, USA). For AuNPrs, TEM images were obtained using a Philips CM 120 transmission electron microscope with an accelerating voltage of $120 \mathrm{kV}$ and a 300 mesh Formvar/Carbon-Coated Copper grid. For both AuNPs, liquid suspensions were deposited on the microgrid and allowed to stand overnight before TEM image acquisition.

\subsection{Peptide Synthesis}

We synthesized the all-D peptide derived from D-amino acids for this study due to their enhanced enzymatic stability [65]. Arginine-rich peptide $\left(\mathrm{r}_{8}\right)$ was synthesized by solid phase peptide synthesis (SPPS), using an H-Rink Amide Protide resin (loading: $0.56 \mathrm{mmol} / \mathrm{g}$ ) in a Liberty Blue ${ }^{\mathrm{TM}}$ Automated Microwave Peptide Synthesizer. Linear D-OctoArginine was synthesized on a $0.5 \mathrm{mmol}$ scale using a 5 excess of Fmoc-amino acid $(0.2 \mathrm{M})$, relative to the resin. The Bromo acetic acid was coupled using 2 cycles of $30 \mathrm{~min}$ of 4 equivalents of OxymaPure, followed by 4 equivalents of $\mathrm{N}, \mathrm{N}^{\prime}$-Diisopropylcarbodiimide, and then 4 equivalents of bromo acetic acid. Fmoc deprotection was carried out using $10 \%(w / v)$ piperazine and 0.1 M OxymaPure in a 9:1 mixture of NMP and EtOH. The 
resin was cleaved using TFA $/ \mathrm{H}_{2} \mathrm{O} / \mathrm{TIS}(95 \% / 2.5 \% / 2.5 \%)$ for $6 \mathrm{~h}$; the TFA was evaporated, dissolved in a 50/50 $\mathrm{H}_{2} \mathrm{O} / \mathrm{ACN}$ solution, and lyophilized. The peptide was purified by semi-preparative HPLC on a Waters 2700 sample manager, equipped with a Waters 2487 dual-wavelength absorbance detector, a Waters 600 controller, a Waters fraction collector and Masslynx software by using a Sunfire C18 column $(150 \times 10 \mathrm{~mm} \times 3.5 \mu \mathrm{m}, 100 \AA$, Waters), flow rate $6.6 \mathrm{~mL} / \mathrm{min}$; solvent $\mathrm{A}=0.1 \%$ TFA in water and solvent $\mathrm{B}=0.1 \%$ TFA in acetonitrile. Purity and identity were assessed by UPCL (Waters Acquity equipped with Acquity photodiode array detector, flux rate $0.610 \mathrm{~mL} / \mathrm{min}$, Acquity UPLC BEH C18 Column, $130 \AA$, $1.7 \mu \mathrm{m}, 2.1 \mathrm{~mm} \times 100 \mathrm{~mm}$; solvents $\mathrm{A}=0.045 \%$ TFA in water, and $\mathrm{B}=0.036 \%$ TFA in acetonitrile) and UPLC-MS (Waters Acquity UPLC System equipped with ESI-SQ Detector2, flux rate $0.610 \mathrm{~mL} / \mathrm{min}$, Acquity UPLC BEH C18 Column, $130 \AA$, $1.7 \mu \mathrm{m}, 2.1 \mathrm{~mm} \times 100 \mathrm{~mm}$; solvents $\mathrm{A}=0.1 \%$ formic acid in water and $\mathrm{B}=0.1 \%$ formic acid in acetonitrile).

The crude compound was purified by RP-HPLC at a semi-preparative scale and characterized by UPLC and UPLC-MS spectrometry (Supplementary Section 1, Figures S1 and S2) to confirm the identity of the synthesized compound, obtaining high purity (>95\%). Amino acid content was analyzed by amino acid analysis; results are presented in Supplementary Section 2, Table S1.

\subsection{BSA Functionalization}

BSA was functionalized with $r_{8}$, as represented in Scheme 1, to improve the internalization properties of the nanoconstructs, and Atto-565-NHS-ester was used as a fluorescent probe for detection by fluorescence and confocal microscopy.

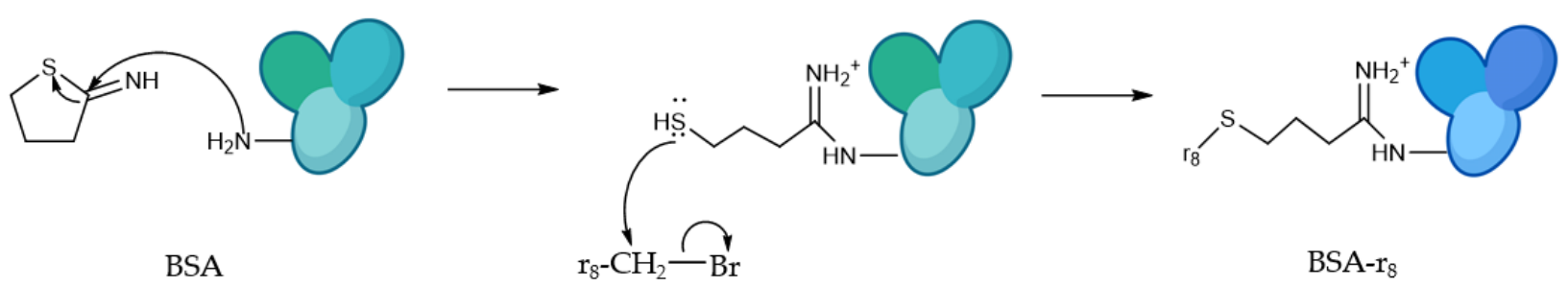

Scheme 1. Synthetic approach for BSA functionalization by $\mathrm{r}_{8}$ peptide. First, 2-iminothiolane reacts with BSA amine groups in the surface of the protein, giving rise to available $\mathrm{SH}$ free groups, followed by $\mathrm{r}_{8}$-Br reaction with the free $\mathrm{SH}$ groups.

BSA Labeling with $\mathrm{r}_{8}$ and Atto 565

- $\quad$ First step: 2-Iminothiolane functionalization

A $100 \mathrm{mg} / \mathrm{mL}$ 2-Iminothiolane solution $(15 \mu \mathrm{L})$ was added to a $10 \mathrm{mg} / \mathrm{mL}$ BSA solution (50 mg of BSA in $5 \mathrm{~mL}$ of PBS), in 4 intervals every $10 \mathrm{~min}$ (molar ratio 10:1 2-iminothiolane: BSA), and the reaction was performed for $1 \mathrm{~h}$ at $4{ }^{\circ} \mathrm{C}$. The non-reacted 2-iminothiolane was removed using a P10 G25 desalting column from Sigma-Aldrich.

- Second step: $r_{8}$ peptide functionalization

To the previously prepared protein, $52 \mu \mathrm{L}$ of a $100 \mathrm{mg} / \mathrm{mL} \mathrm{Br}-\mathrm{CH}_{2}-\mathrm{r}_{8}$ solution was added in 4 intervals every $10 \mathrm{~min}$, and the reaction was left overnight at $4{ }^{\circ} \mathrm{C}$ (ratio $5: 1$ $\mathrm{r}_{8}$-Br:BSA). The product was purified with a P10 G25 desalting column and analyzed by UV-Vis-NIR spectroscopy and amino acid analysis to determine the amount of $\mathrm{r}_{8}$ per BSA molecule.

- Third step: amino acid analysis of BSA-r 8

Amino acid analysis was performed following an acid hydrolysis procedure, adding $12 \mathrm{~N} \mathrm{HCl}$ and a known concentration standard $(~(-$-aminobutyric acid, $0.1 \mathrm{mM})$, and allowed to react at $110^{\circ} \mathrm{C}$ for $72 \mathrm{~h}$. Amino acid quantification was carried out in an HPLC-PDA AccQ-Tag $(\mathrm{C} 18 ; 4 \mu \mathrm{m} ; 3.9 \times 15 \mathrm{~mm})$. The amino acid content on the functionalized BSA resulted in a $2.4 \mathrm{r}_{8} / \mathrm{BSA}$ ratio, as shown in Supplementary Section 2, Table S1. 


\section{- $\quad$ BSA-r $r_{8}$ fluorescent labeling}

Fluorescent labeling of BSA was conducted as represented in Scheme 2. To $10 \mathrm{mg}$ of BSA-r 8 of the previous step, $10.7 \mu \mathrm{L}$ of a $10 \mathrm{mg} / \mathrm{mL}$ solution of Atto $565 \mathrm{NHS}$ ester was added and allowed to react for $1 \mathrm{~h}$. The final product (BSA-r $\left.\mathrm{r}_{8}-\mathrm{A} 565\right)$ was purified with a P10 G25 desalting column and characterized by UV-Vis spectroscopy.

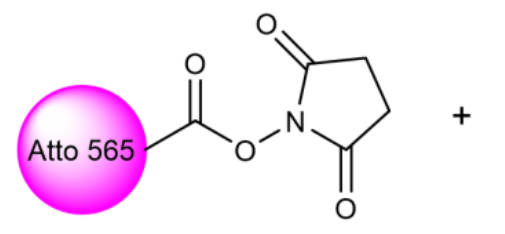

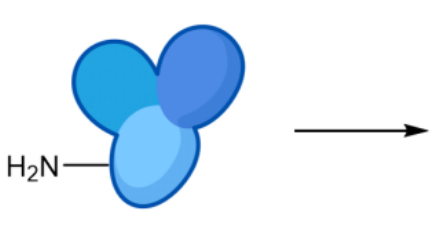

BSA-r8

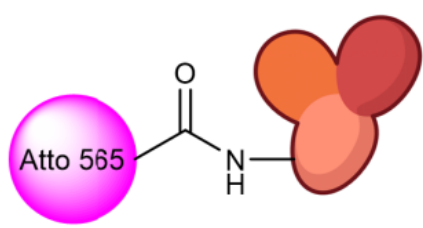

BSA-r8-A565

Scheme 2. Synthetic approach for BSA-r $\mathrm{r}_{8}$ functionalization by Atto565-NHS ester in the $\mathrm{NH}_{2}$ free groups of BSA.

According to UV-Vis spectroscopy measurements, the degree of labeling (DOL) was calculated as follows:

$$
D O L=\frac{\text { Absorbance } 565 \times \varepsilon_{\text {Atto } 565}}{\text { Absorbance } 280\left(\text { Absorbance } 565 \times C F_{\text {Atto } 565}\right) \times \varepsilon_{B S A}}
$$

where:

$E_{\text {Atto } 565}=1.2 \times 10^{5} \mathrm{M}^{-1} \mathrm{~cm}^{-1}, E_{B S A}=4.6 \times 10^{5} \mathrm{M}^{-1} \mathrm{~cm}^{-1}$, and correction factor Atto $565\left(C F_{\text {Atto } 565}\right)=0.16$

As a result, the DOL of BSA-r $\mathrm{r}_{8}$ A565 was $0.66 \mathrm{~mol}$ Atto/mol BSA.

\subsection{Circular Dichroism}

The BSA and BSA-r $\mathrm{r}_{8} 1.5 \times 10^{-5} \mathrm{M}$ samples were prepared in PBS $0.1 \times$ in the same conditions. The spectra were acquired at $20{ }^{\circ} \mathrm{C}$, recorded from 200 to $250 \mathrm{~nm}$ in triplicate and condensed into a single spectrum to reduce noise at a $1 \mathrm{~nm} / \mathrm{s}$ rate in a JASCO J-815 instrument (JASCO, Easton, MA, USA), using a $1 \mathrm{~mm}$ pathlength quartz-cuvette. The secondary structure content was calculated using the CDPro CONTIN 2DP (AUG 1982) (2DP-SW PACK) version from JASCO.

The molar ellipticity at wavelength $\lambda\left(\left[\theta_{\mathrm{mrw}}\right]\right)$ was calculated as follows:

$$
\left[\theta_{\mathrm{mrw}}\right]=\frac{M R W \times \theta_{\lambda}}{10 \times d \times c}
$$

where $\theta_{\lambda}$ is the observed ellipticity (degrees) at wavelength $\lambda, d$ is the pathlength $(\mathrm{cm})$, and $c$ is the protein concentration $(\mathrm{g} / \mathrm{mL})[66]$.

\subsection{Capping of $A u N P s$ with $B S A$ or $B S A-r_{8}$}

BSA- $r_{8}$ or BSA capping of the AuNPs was achieved by incubation, as previously reported [36]. Briefly, to $1 \mathrm{~mL}$ of AuNRs or AuNPrs at a $1 \mathrm{nM}$ concentration, a solution of BSA or BSA-r $r_{8}$ was added (final concentration of BSA $=1 \mathrm{mg} / \mathrm{mL}$ in $0.1 \times \mathrm{PBS}$ ), incubating for $2 \mathrm{~h}$ at $4{ }^{\circ} \mathrm{C}$ in low-binding $1.5 \mathrm{~mL}$ centrifuge tubes (Eppendorf ${ }^{\circledR}$, Hamburg, Germany), and the samples were centrifuged at $10,000 \mathrm{rpm}$ for $10 \mathrm{~min}$. The pellet containing the BSA or BSA-r $r_{8}$ coated AuNPs was resuspended in $0.1 \times$ PBS. The protein content was quantified on the supernatants using a Micro BCA ${ }^{\mathrm{TM}}$ Protein Assay Kit from Thermo Scientific ${ }^{\mathrm{TM}}$ (Pierce, Rockford, IL, USA), according to the manufacturer's specifications, in triplicate.

\subsection{Cell Culture}

HeLa cells were cultured in complete DMEM, containing 1\% penicillin/streptomycin, $10 \% \mathrm{FBS}$ and $5 \%$ glutamine. The culture was maintained at $37{ }^{\circ} \mathrm{C}$ and $5 \% \mathrm{CO}_{2}$. 


\subsubsection{Cell Viability MTS Assays}

HeLa cells $\left(1 \times 10^{4}\right.$ cells/well $)$ were seeded in TC pretreated 96-well plates and allowed to attach at $37^{\circ} \mathrm{C}$ for $24 \mathrm{~h}$. The treatments were added and allowed to incubate for $24 \mathrm{~h}$. The medium was then replaced by a phenol red-free medium containing the MTS/PMS containing reagent, following the manufacturer's recommendations. The absorbance of the culture medium after incubation for $1 \mathrm{~h}$ was recorded at $490 \mathrm{~nm}$ using a microplate reader. Cell viability was calculated with respect to a non-treatment control (live control). Each treatment and control were made in quintuplicate, minimum $n=3$. Statistical analysis was performed using GraphPad Prism V5.01.

\subsubsection{Confocal Microscopy}

HeLa cells $\left(3 \times 10^{5}\right.$ cells / plate) were seeded on collagen pre-coated MatTek glassbottom culture dishes (MatTek Corporation, Ashland, MA, USA) and attached for $48 \mathrm{~h}$ at standard culture conditions. The medium was then replaced with fresh medium, and the treatments were added considering $1 \mathrm{nM}$ of each AuNP and incubated ( 1 or $24 \mathrm{~h}$ of treatment). The cells were subsequently washed 3 times with PBS, and phenol red-free medium containing the LIVE/DEAD ${ }^{\circledR}$ Cell Imaging Kit from ThermoFisher was added (Molecular Probes Inc., Eugene, OR, USA). Fluorescence was detected on a Zeiss LSM 880 laser scanning microscope (Zeiss, Berlin, Germany) with Airyscan, equipped with a $\mathrm{CO}_{2}$ and temperature-controlled environmental chamber. Hoechst was excited with an Ar laser at $405 \mathrm{~nm}$, and emission was recorded at $458 \mathrm{~nm}$; Atto- 565 was excited by a laser at $405 \mathrm{~nm}$, and emission was recorded at $458 \mathrm{~nm}$. Images were processed using Image J $1.52 \mathrm{p}$ software.

\subsubsection{Internalization Evaluated by Transmission Electron Microscopy}

In a Petri dish $(90 \times 15 \mathrm{~mm}), 1 \times 10^{6} \mathrm{HeLa}$ cells were seeded and incubated at $37^{\circ} \mathrm{C}$ until a minimum confluence of $80 \%$. The cells were then washed, the medium was replaced with a treatment containing-medium ( $1 \mathrm{nM}$ of BSA or BSA-r 8 coated AuNPs), and the cells were incubated for $24 \mathrm{~h}$. Afterwards, the cells were washed and fixed with glutaraldehyde $2.5 \%$ in PBS $0.1 \times$. The cells were scraped and centrifuged, and the obtained pellet was fixed with $\mathrm{OsO}_{4} 1 \%$ in PBS for 90 min and embedded in Epon resin. The resin was sliced into slices of $80 \mathrm{~nm}$ thickness, and the slices were placed in a $\mathrm{Cu}$ grid and stained with Reynold's reagent and uranyLess staining kit, before visualization. TEM images were acquired in a JEOL JEM-1010 microscope (JEOL Ltd., Tokyo, Japan).

\section{Results and Discussion}

\subsection{Preparation of $A u N R s-B S A-r_{8}$ and $A u N P r-B S A-r_{8}$}

The $\mathrm{r}_{8}$ peptide was synthesized and characterized by UPLC-MS, showing the characteristic $[\mathrm{M}+2 \mathrm{H}]^{2+}=695.02 \mathrm{~m} / \mathrm{z}$ (Figure S1). Then, BSA was functionalized with $\mathrm{r}_{8}$ ( $\left.2.4 \mathrm{r}_{8} / \mathrm{BSA}\right)$ as described in the experimental section. The degree of BSA functionalization was determined by amino acid analysis, resulting in $2.4 \mathrm{r}_{8} / \mathrm{BSA}$. To determine if the functionalization of the protein led to a change in BSA secondary structure, circular dichroism spectra were obtained. Figure 1 shows the CD spectrum of BSA and BSA- $\mathrm{r}_{8}$, indicating that they shared a similar profile, with a non-significant change from $39 \%$ and $36 \%$ alpha helix content before and after $r_{8}$ functionalization, respectively.

BSA-r 8 was functionalized with a fluorescent probe, namely A565, a known and commonly used red fluorescent probe, obtaining a 0.66 A565/BSA-r $r_{8}$ degree of labeling, which resulted in BSA-A565-r. . In this study, we tested whether AuNPrs were a suitable alternative to more-traditional AuNRs; in this sense, AuNPrs were synthesized by simply reducing $\mathrm{Au}^{3+}$ with $\mathrm{Na}_{2} \mathrm{~S}_{2} \mathrm{O}_{3}$, thus avoiding the involvement of cytotoxic agents [28]. AuNRs and AuNPrs were synthesized with a characteristic morphology, as TEM images show in Supplementary Section 3 (Figures S3 and S4), with a predominant aspect ratio of 3.5 for AuNRs and a $60 \mathrm{~nm}$ edge-length for AuNPrs. 


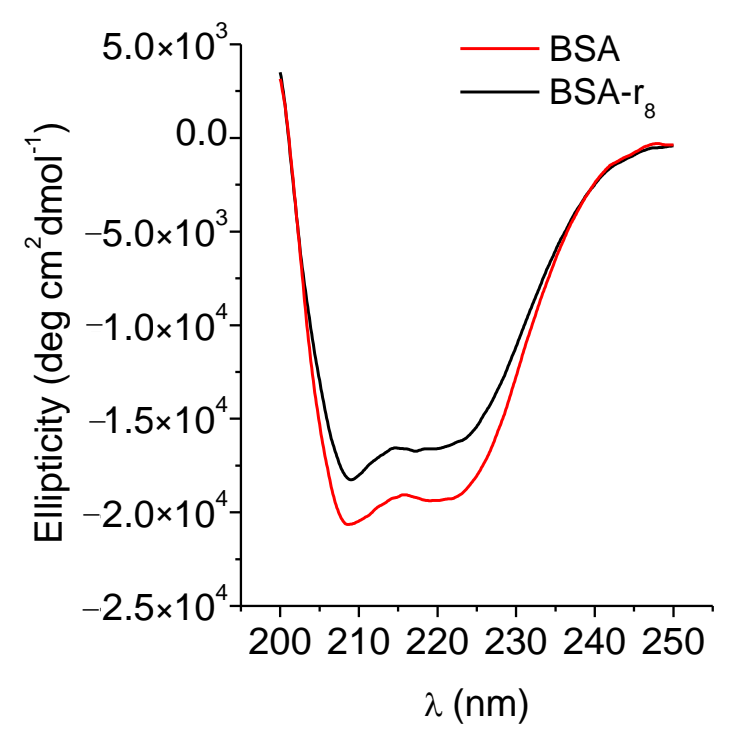

Figure 1. Circular dichroism spectrum of BSA before and after $r_{8}$ functionalization. DOL: $2.4 r_{8} / B S A$. BSA and BSA-r $8.5 \times 10^{-5} \mathrm{M}$ samples were prepared in PBS.

It has been demonstrated by several spectroscopic techniques that BSA is spontaneously adsorbed in the surface of AuNPs via S-Au bonds between the free SH groups of BSA and the gold atoms in the AuNP surface [42,67-71]. Therefore, both AuNRs and AuNPrs were coated with BSA and the functionalized BSA-A565- $\mathrm{r}_{8}$ by incubation, as summarized in Table 1 and Figures 2 and 3. Figures 2 and 3 show the UV-Vis-NIR spectra, size, and $\mathrm{Z}$ potential of the BSA and BSA-A565- $\mathrm{r}_{8}$ functionalized AuNPs in PBS $(\mathrm{pH}=7)$. For AuNRs, a shoulder around $558 \mathrm{~nm}$ appeared after BSA-A565-r 8 protein coating (Figure 2a), as well as an increment in the intensity of the first plasmon in AuNPrs (Figure 3a), confirming the presence of A565 and therefore, the functionalization of BSA on the AuNPs surface. In addition, the second plasmon of both AuNPs was shifted after the BSA and BSA-r8A565 coating, attributed to the modification in the dielectric constant of the AuNPs [72] (Table 1 and Figures 2a and 3a), due to the presence of the protein on the AuNPs surface, as reported in previous studies [36,73-75].

For both nanoparticles, the protein coating on the surface increased the hydrodynamic diameter in similar proportions using either the BSA or BSA-A565- $\mathrm{r}_{8}$, as expected for the presence of the protein (Table 1 and Figures $2 b$ and $3 b$ ). For AuNRs, hydrodynamic diameter increased from $2 \pm 1,59 \pm 3 \mathrm{~nm}$ to $3 \pm 1,68 \pm 3 \mathrm{~nm}$ and $6 \pm 1,79 \pm 3 \mathrm{~nm}$ after the BSA and BSA-A565- $\mathrm{r}_{8}$ coating, respectively. Meanwhile, for AuNPrs, the hydrodynamic diameter shifted from $4 \pm 1,68 \pm 4 \mathrm{~nm}$ to $10 \pm 2,142 \pm 5 \mathrm{~nm}$ and $12 \pm 2,142 \pm 5 \mathrm{~nm}$ due to the BSA and BSA-A565-r 8 coating, respectively.

Regarding the $\mathrm{Z}$ potential, a similar trend was observed, and both nanoparticles showed similar $Z$ potentials after the BSA or BSA-A565- $r_{8}$ coating. AuNRs showed an initial $\mathrm{Z}$ potential of $+45 \pm 3 \mathrm{mV}$, due to the presence of the cationic surfactant CTAB [76,77]; in contrast, AuNPrs had an initial Z potential of $-31 \pm 3 \mathrm{mV}$, due to the stabilizing agent HS-PEG-COOH on the surface [36]. Then, the $Z$ potential exhibited a shift to negative values; $-21 \pm 1$ and $-17 \pm 1$ for AuNR-BSA and AuNR-BSA-A565- $\mathrm{r}_{8}$ and $-14 \pm 1$ and $-18 \pm 1 \mathrm{mV}$ for AuNPr-BSA and AuNPr-BSA-A565- $\mathrm{r}_{8}$, respectively (Table 1 and Figures $2 \mathrm{c}$ and $3 \mathrm{c}$ ), due to the negative charge of BSA (pI $\mathrm{BSA}_{\mathrm{BS}}: 4.5-5.0$ ) [78] on the surface of both AuNPs. Notably, AuNPs exhibited similar negative Z potentials, with adequate values to interact with cell membranes for internalization [60-62]. Stability of AuNR-BSA-r ${ }_{8}$ and AuNPr-BSA-r ${ }_{8}$ was assessed 30 days after storage at $4{ }^{\circ} \mathrm{C}$; DLS and Z potential did not show significant differences over that time (Supplementary Section 4 , Figure S5). 
Table 1. Physicochemical parameters of the synthesized nanoparticles and nanoconstructs.

\begin{tabular}{|c|c|c|c|c|c|}
\hline \multirow{2}{*}{ Samples } & \multirow{2}{*}{ Long. $\lambda_{\max }(\mathrm{nm})$} & \multicolumn{2}{|c|}{ Hydrodynamic Diameter (nm) } & \multirow{2}{*}{ PDI } & \multirow{2}{*}{ Z Potential (mV) } \\
\hline & & Transversal & Longitudinal & & \\
\hline AuNR & 775 & $2 \pm 1$ & $59 \pm 3$ & 0.5 & $45 \pm 3$ \\
\hline AuNR-BSA & 757 & $3 \pm 1$ & $68 \pm 3$ & 0.5 & $-21 \pm 1$ \\
\hline AuNR-BSA-A565-r 8 & 750 & $6 \pm 1$ & $79 \pm 3$ & 0.5 & $-17 \pm 1$ \\
\hline AuNPr & 865 & $4 \pm 1$ & $68 \pm 4$ & 0.4 & $-31 \pm 3$ \\
\hline AuNPr-BSA & 845 & $10 \pm 2$ & $142 \pm 5$ & 0.5 & $-14 \pm 1$ \\
\hline AuNPr-BSA-A565- $\mathrm{r}_{8}$ & 829 & $12 \pm 2$ & $142 \pm 5$ & 0.5 & $-18 \pm 1$ \\
\hline
\end{tabular}

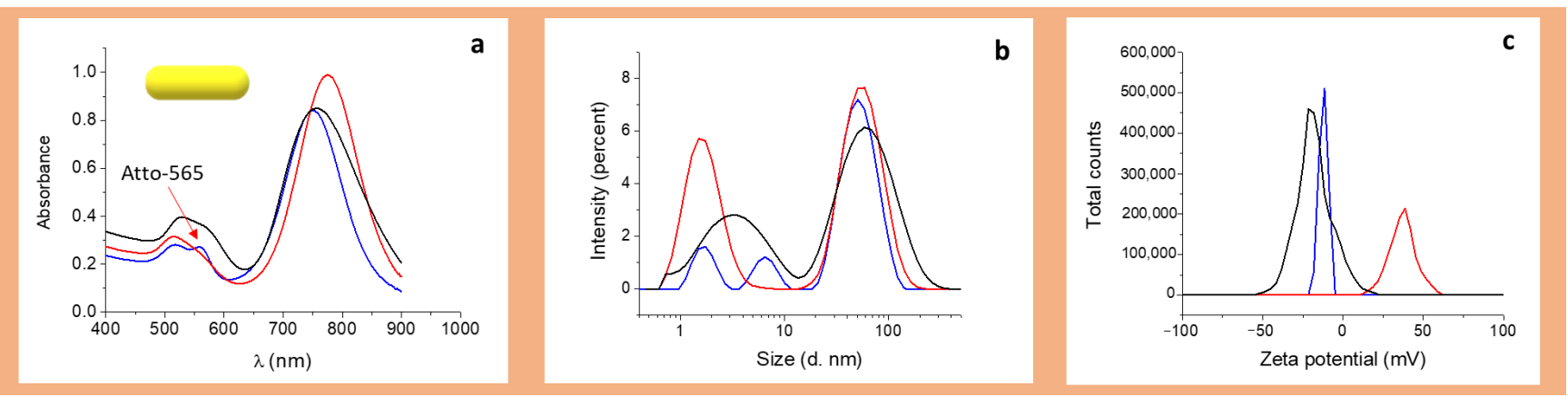

Figure 2. Characterization of BSA-A565- $\mathrm{r}_{8}$ capped AuNRs: red line, AuNRs, black line AuNR-BSA, blue line AuNR-BSA-

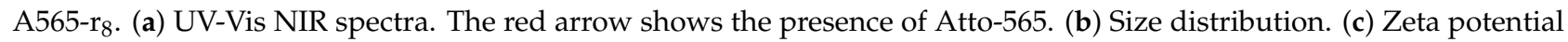
distribution. Acquired in PBS, $\mathrm{pH}=7$.
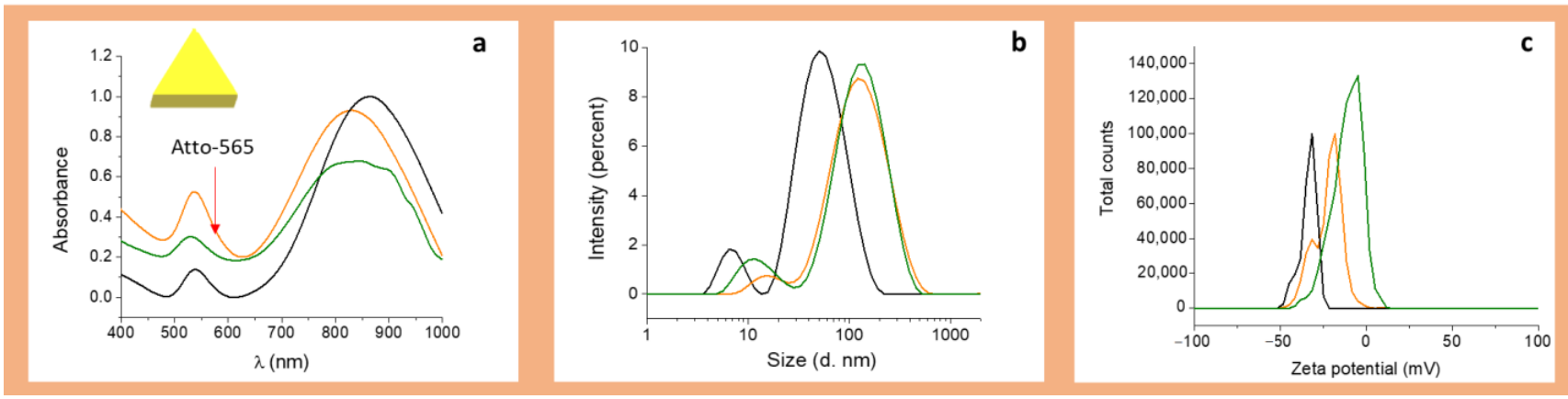

Figure 3. Characterization of BSA-A565- $\mathrm{r}_{8}$ capped AuNPrs; black line AuNPrs, green line AuNPr-BSA, and orange line AuNPr-BSA-A565-r. . (a) UV-Vis-NIR spectra. The red arrow shows the presence of Atto-565. (b) Size distribution. (c) Zeta potential distribution. Acquired in PBS, $\mathrm{pH}=7$.

\subsection{Cell Viability Assays}

3.2.1. Effect of AuNRs and AuNRs-BSA-A565- $\mathrm{r}_{8}$ on Cell Viability

One of the main limitations of using AuNRs in biomedical applications is the cytotoxicity associated with the CTAB on the AuNP surface as the stabilizing agent in the synthesis procedure [30]. In order to overcome this issue, AuNRs can be coated with different materials, such as BSA [39,79-82] to increase their biocompatibility. In this regard, Figure 4 shows that the freshly synthesized AuNRs drastically decreased the viability of Hela cells, whereas AuNRs-A565-BSA- $r_{8}$ did not cause a significant effect between the $0.005-2.5 \mathrm{nM}$ range at $48 \mathrm{~h}$. Additionally, flow cytometry showed no effect of $1 \mathrm{nM}$ AuNRs-A565-BSA-r 8 after $24 \mathrm{~h}$ of administration (Supplementary Section 5, Figure S6). Similar results were found for BSA-coated AuNPs in previous studies; the BSA coating on AuNRs improved their biocompatibility properties [83-85], highlighting the potential of coated AuNRs for bioapplications. 
Cell viability of HeLa cells treated with AuNRs for $48 \mathrm{~h}$

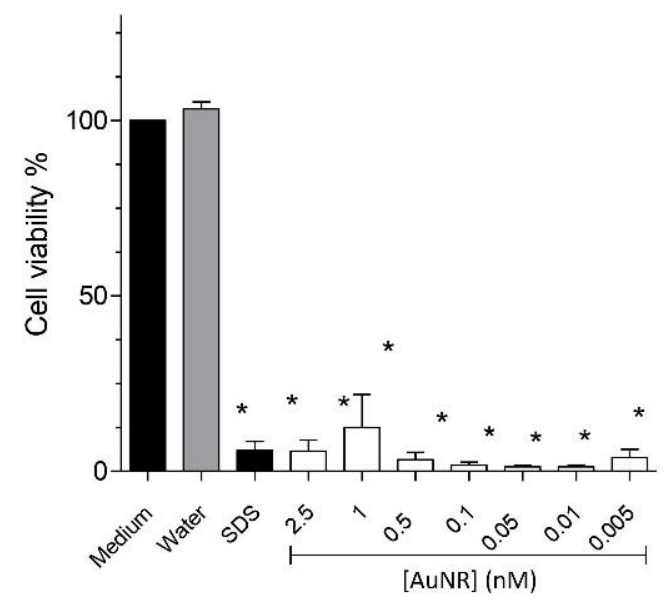

Cell viability of HeLa cells treated with AuNRs-BSA-A565- $r_{8}$ for $48 \mathrm{~h}$

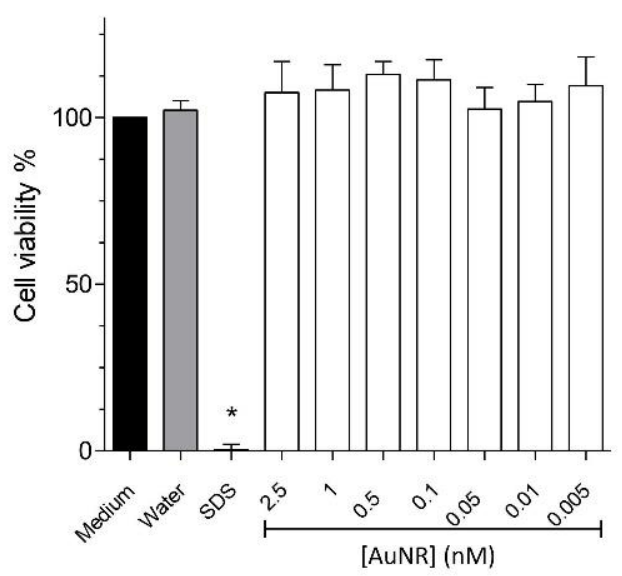

Figure 4. Effect of AuNRs and AuNR-BSA-r ${ }_{8}$ incubated for $24 \mathrm{~h}$ on cell viability of HeLa cells at $48 \mathrm{~h}$. The average values for $n=4$ experiments are shown with error bars representing the SEM. * Significant difference according to Tukey's test $p<0.05$ compared to medium control.

\subsubsection{Effect of AuNPrs and AuNPrs-BSA-r $\mathrm{r}_{8}$ on Cell Viability}

AuNPrs were functionalized with PEG-COOH to increase their colloidal stability [86] and subsequently coated with BSA-A565- $\mathrm{r}_{8}$ (AuNPr-BSA-A565- $\mathrm{r}_{8}$ ). Figure 5 shows cell viability of HeLa cells treated with AuNPrs and AuNPr-BSA-A565- $\mathrm{r}_{8}$ at the $0.005-2.5 \mathrm{nM}$ range. As expected, neither AuNPrs nor AuNPrs-BSA-r 8 showed any effect on HeLa cell viability after $48 \mathrm{~h}$ of treatment by MTS assay. Flow cytometry also showed non-effect of AuNPrs-BSA-r $1 \mathrm{nM}$ in the HeLa cells after $24 \mathrm{~h}$ of incubation (Supplementary Section 5, Figure S6). This null effect on cell viability of AuNPrs was previously demonstrated in studies such as those of Alfranca et al. and Bao et al., using Vero cells and HT-29 cells at $72 \mathrm{~h}$, respectively $[29,87]$
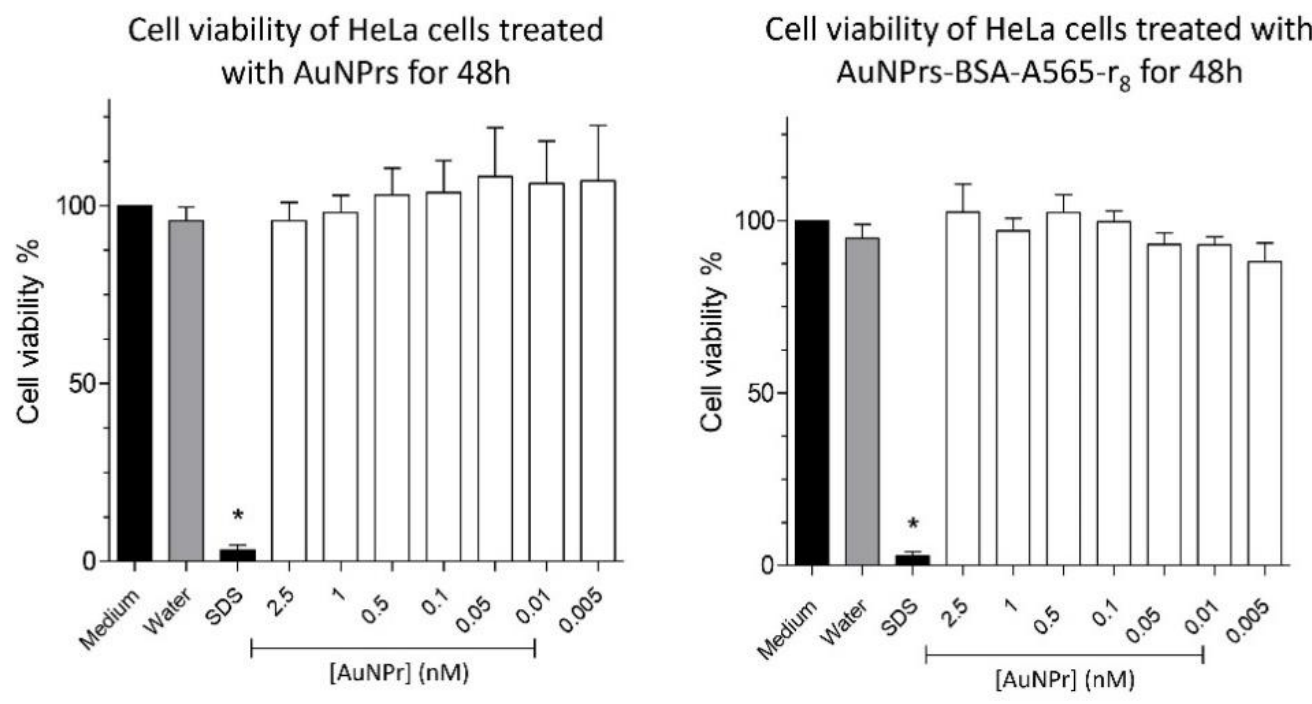

Figure 5. Effect of AuNPrs and AuNPr-BSA-r r $_{8}$ incubated for $24 \mathrm{~h}$ on cell viability of HeLa cells at $48 \mathrm{~h}$. The average values for $n=4$ experiments are shown with error bars representing the SEM. * Significant difference according to Tukey's test $p<0.05$ compared to medium control. 


\subsection{Cell Internalization}

\subsubsection{Confocal Microscopy}

In a first step, we tested the internalization ability of the AuNPs capped with non-CPP functionalized BSA, as shown in Figure 6. The comparison between the BSA, AuNR-BSA, and AuNPr-BSA (labeled with A565) signals showed that BSA on the AuNP surface was not able to promote cell uptake under the studied conditions ([BSA] $=5 \mu \mathrm{M}$, [AuNR-BSA and AuNPr-BSA] $=1 \mathrm{nM}, 24 \mathrm{~h}$ of incubation), as demonstrated by the absence of signal in the red channel.

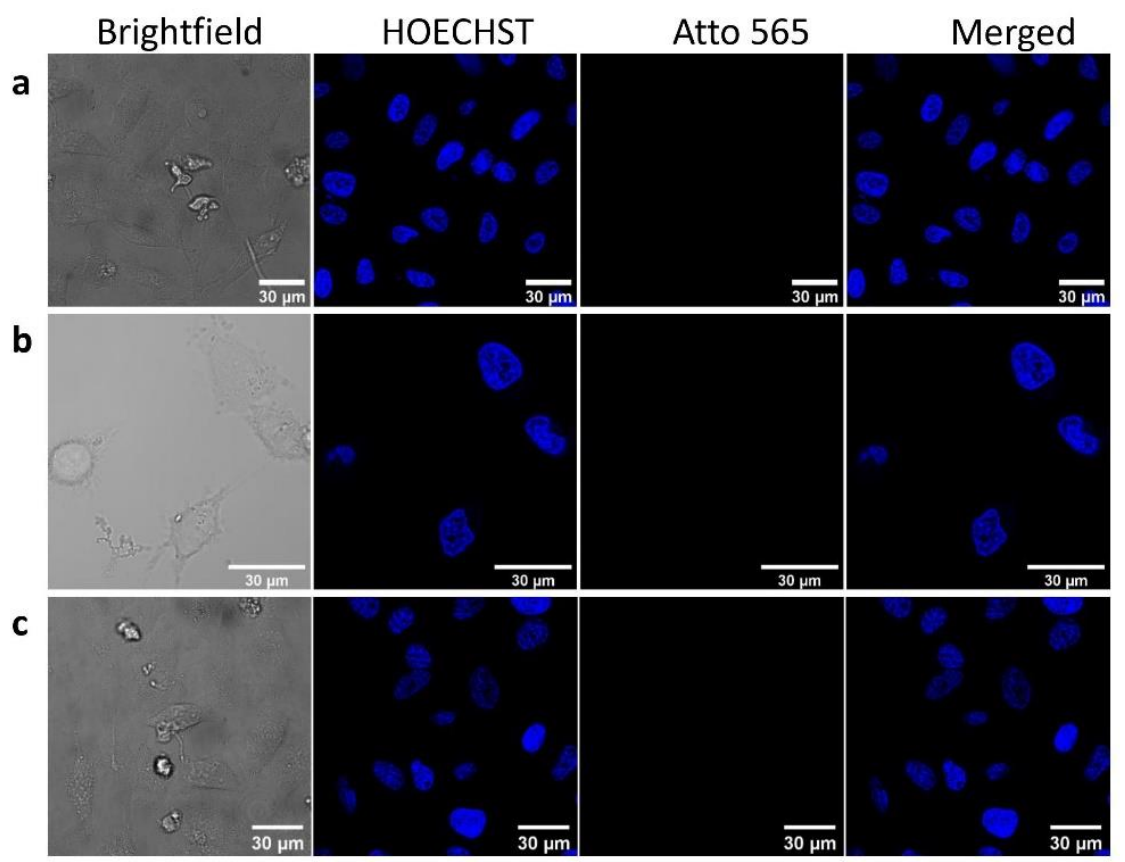

Figure 6. Confocal microscopy images of HeLa cells after treatment by: (a) BSA-A565, (b) AuNRBSA-A565, (c) AuNPr-BSA-A565 incubated for $24 \mathrm{~h}$. Scale $30 \mu \mathrm{m}$. [BSA] $=5 \mu \mathrm{M}$, [AuNR-BSA, AuNPr-BSA] $=1 \mathrm{nM}$. Channels: bright blue (HOECHST), red (Atto-565), blue and red (merged).

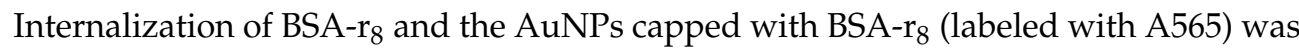
subsequently assessed by confocal microscopy. As Figure 7 shows, functionalization with $\mathrm{r}_{8}$ increased the uptake of the protein, as well as that of the protein-coated AuNRs and AuNPrs in the red channel, using the same established conditions as in Figure 7 ([BSA] $=5 \mu \mathrm{M}$, [AuNR-BSA-A565- $\mathrm{r}_{8}$ ] and [AuNPr-A565- $\left.\mathrm{r}_{8}\right]=1 \mathrm{nM}$ ), suggesting the prevalent role of the $\mathrm{r}_{8}$ for cell internalization in both nanoconstructs, regardless of their surface charge.

Although discussing the exact mechanism of internalization of the proposed nanoconstructs was not the objective of our study, previous reports have indicated that nanoconstructs conjugated with CPPs are internalized in vesicles inside cells via endocytic uptake $[29,51,59,88]$, while arginine-rich CPPs can electrostatically bind with the cell membranes, promoting translocation into the cells $[29,51,59,88]$.

To confirm that the internalization observed through confocal microscopy corresponded to the functionalized AuNPs, and to elucidate the intracellular location of the nanoconstructs in Hela cells, we performed a TEM study, as indicated in the next section.

\subsubsection{TEM for Cell Internalization}

The internalization of the BSA-A565-r 8 -coated AuNPs was assessed after $1 \mathrm{~h}$ and $24 \mathrm{~h}$ of incubation. Supplementary Section 6 (Figures S7 and S8) shows internalization at $1 \mathrm{~h}$, indicating that the nanoconstructs started interacting with the cell membranes at this time, to become ready for the internalization process. At $24 \mathrm{~h}$, in contrast, internalization of both AuNRs-BSA-A565- $\mathrm{r}_{8}$ and AuNPr-BSA-A565- $\mathrm{r}_{8}$ was considerable and observed under the studied conditions, as shown in Figures 8 and 9. 


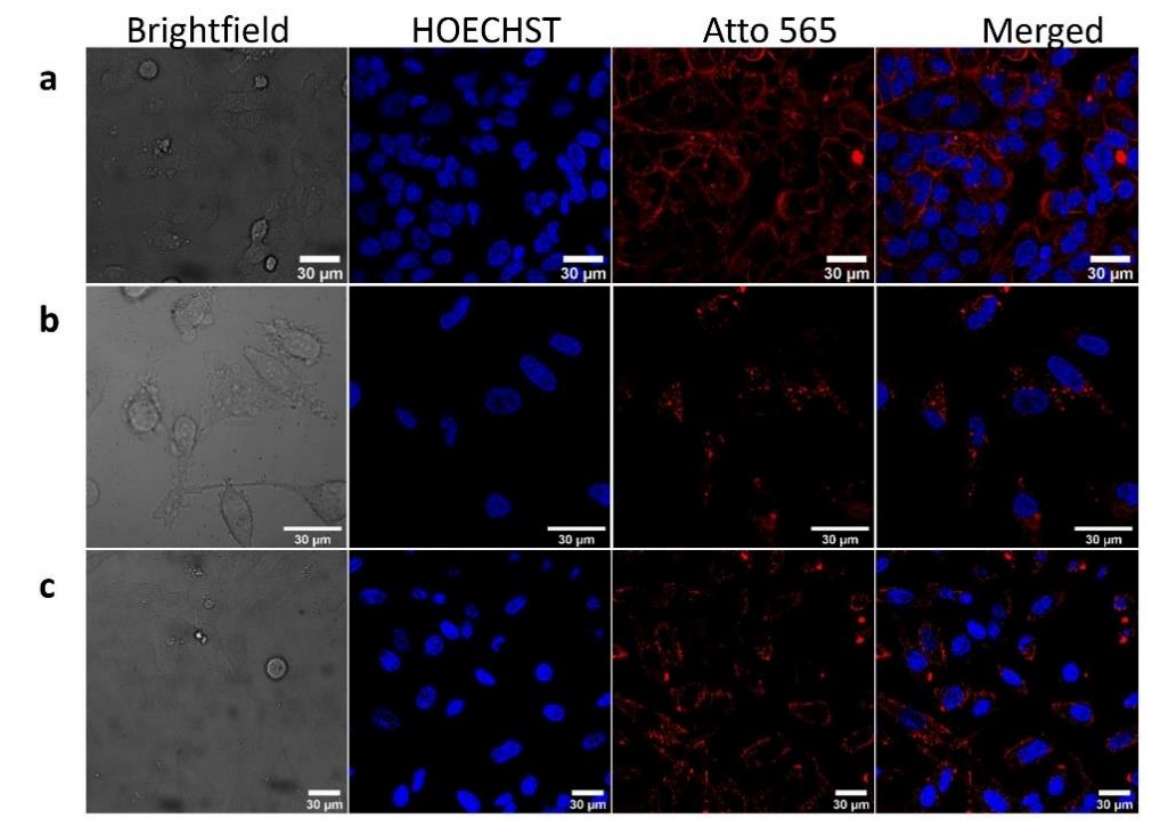

Figure 7. Confocal microscopy images of HeLa cells after treatment with: (a) BSA-r 8 -A565, (b) AuNRBSA-r 8 -A565, (c) AuNPr-BSA-r $r_{8}-A 565$ incubated for $24 \mathrm{~h}$. Scale $30 \mu \mathrm{m}$. [BSA-r 8 ] = $5 \mu \mathrm{M}$, [AuNRBSA-A565- $\mathrm{r}_{8}$ and AuNPr-A565-BSA-r 8 ] = $1 \mathrm{nM}$. Channels: bright blue (HOECHST), red (Atto-565), blue and red (merged).
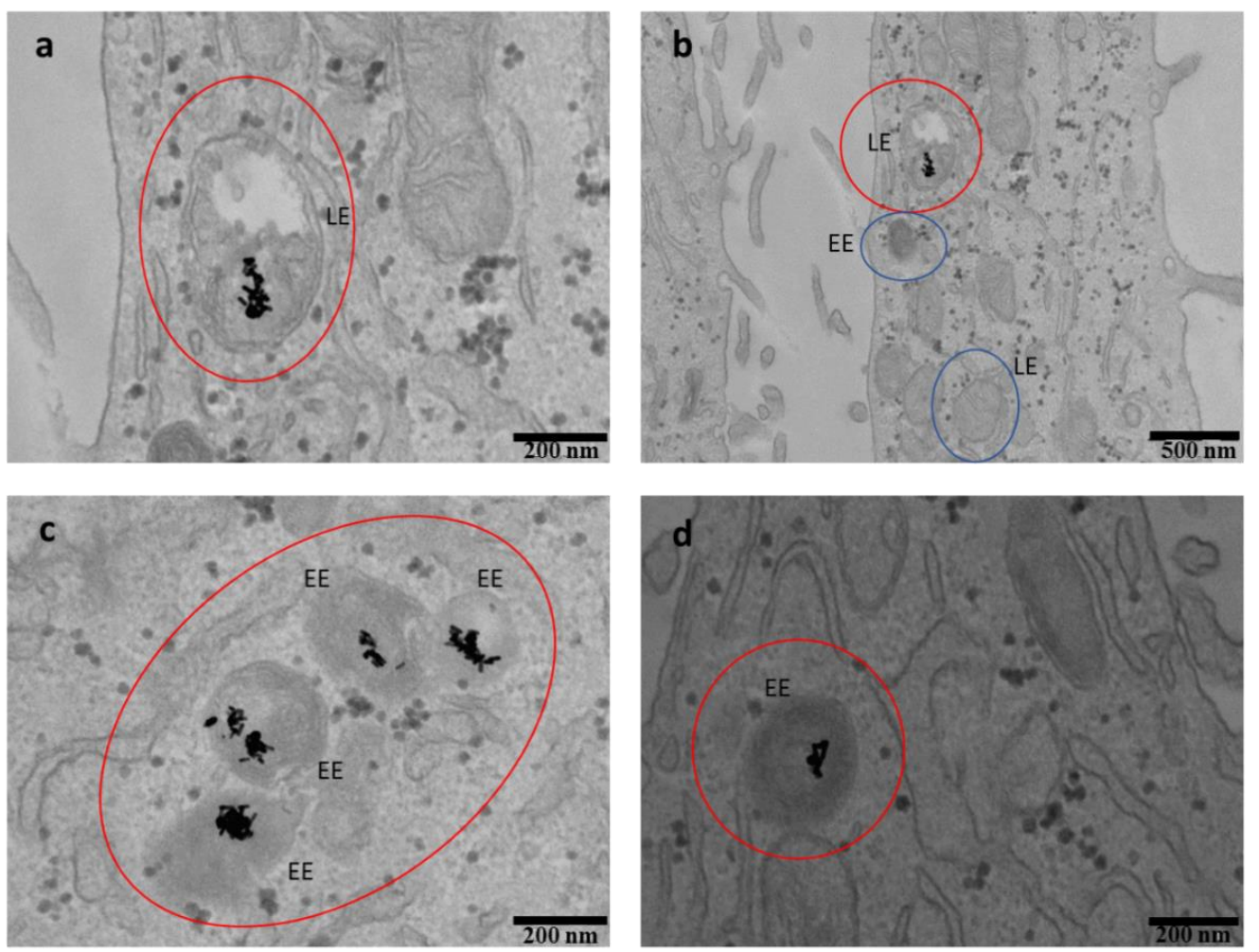

Figure 8. TEM images of HeLa cells after treatment with AuNR-BSA-r $\mathrm{r}_{8}$ incubated for $24 \mathrm{~h}$ (a-d). Red circles show the internalized AuNPs. EE: early endosomes and LE: late endosomes. Blue circles showing examples of vacant LE or EE. 

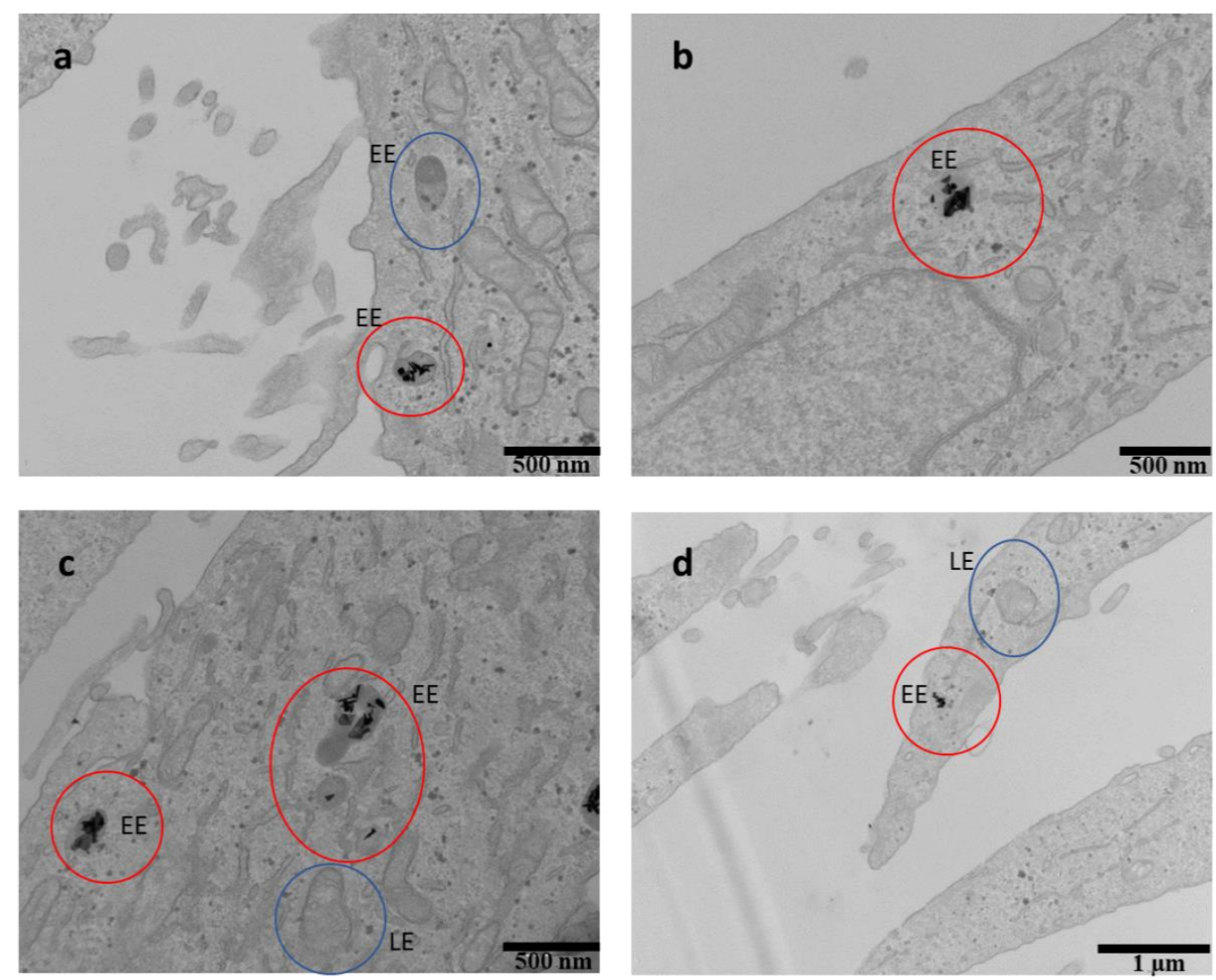

Figure 9. TEM images of HeLa cells after treatment with AuNPr-BSA-r 8 incubated for $24 \mathrm{~h}$ (a-d). Red circles show the internalized AuNPs. EE: early endosomes and LE: late endosomes. Blue circles showing examples of vacant $\mathrm{LE}$ or EE.

The TEM images allowed determination of the precise location of the AuNPs in the cells. Both AuNRs and AuNPrs-based nanocarriers seemed to be located inside the cells and accumulated into vesicles in the cytoplasm, in agreement with the proposed endocytic uptake $[29,51,59,88]$. According to Liu et al. [89], the vesicles were labeled considering their size as early endosomes (200 $\mathrm{nm}$ diameter, EE) and late endosomes ( $500 \mathrm{~nm}$ diameter, LE). In Figures 8 and 9, vacant EE and LE as well as the EE and LE where AuNPs are located were pointed out (blue and red circles, respectively). An average of $15 \pm 5$ AuNRs/vesicle and $18 \pm 6$ AuNPrs/vesicle were counted for AuNRs-BSA-A565-r 8 and AuNPr-BSA-A565$\mathrm{r}_{8}$, respectively (statistics of 30 vesicles from the TEM images).

\section{Conclusions}

In this work, we tested the internalization abilities of two novel nanoconstructs based on anisotropic AuNPs with different surface and charge, AuNRs and AuNPrs coated with BSA in the presence and absence of a CPP $\left(\mathrm{r}_{8}\right)$, improving AuNP internalization in the presence of $r_{8}$. To the best of our knowledge, this is the first report that describes the coating of AuNRs and AuNPrs (with absorption in the first biological window) with BSA functionalized with $r_{8}$ for improved cell internalization. These results point to the ability to improve the biocompatibility and internalization of nanoconstructs into cells by using endogenous proteins and CPPs. Nevertheless, as a further step, it would also be interesting to add targeting agents to the proposed nanoconstructs to increase their selectivity.

Supplementary Materials: The following are available online at https:/ / www.mdpi.com/article/10 .3390/pharmaceutics13081204/s1: Figure S1: Structure of the $\mathrm{Br}_{-} \mathrm{CH}_{2}-\mathrm{r}_{8}$ peptide, Figure S2: UPLC trace (a) and MS spectra (b) of Br- $\mathrm{r}_{8}\left(\mathrm{BrCH} 2 \mathrm{CO}-\mathrm{r}_{8}\right)$, Figure S3: Microscopy characterization of AuNRs: a, b. representative TEM images, scale $200 \mathrm{~nm}$, c. Aspect ratio frequency distri-bution (length/width), 
statistics of at least 50 AuNRs, Figure S4: Microscopy characterization of AuNPrs: a, b. representative TEM images, scale $200 \mathrm{~nm}$, c. Edge length (nm) frequency distribution (length/width), statistics

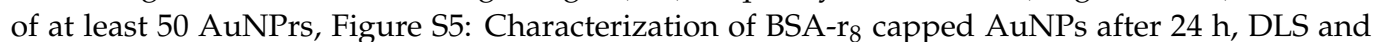
Zeta potential, Figure S6: Flow cytometry of Hela cells incubated by $24 \mathrm{~h}$ with: a. water, b. AuNRBSA-r 1 nM in AuNRs, c. AuNPr-BSA-r 1 nM AuNPrs, Figure S7: TEM images of HeLa cells after treatment by AuNR-BSA-r $r_{8}$ incubated by $1 \mathrm{~h}$, Figure S8: TEM images of HeLa cells after treatment by AuNPr-BSA-r 8 incubated by $1 \mathrm{~h}$, Table S1: Amino acid analysis of BSA-r8 after acid digestion, using $\Upsilon$-aminobutiric acid as standard (aaba).

Author Contributions: Conceptualization, K.B., M.J.K. and E.A.; methodology, K.B., M.S.-N. and A.T.-A.; formal analysis, K.B., M.J.K. and E.A.; resources, E.G., M.J.K. and E.A.; writing-original draft preparation, K.B.; writing-review and editing, all authors; supervision, E.A. and M.J.K.; project administration, E.A. and M.K; funding acquisition, E.G., E.A. and M.J.K. All authors have read and agreed to the published version of the manuscript.

Funding: K.B. acknowledges ANID, Chile, Doctoral fellowship 21180258 and Advanced Center for Chronic Diseases. A.T.-A. acknowledges PhD fellowship number 21151461 and 23190312. E.A. acknowledges Fondecyt 1190623. M.J.K. acknowledges FONDECYT 1211482, FONDAP 15130011 and FONDEQUIP EQM170111. M.S.-N. and E.G. acknowledge MINECO-FEDER (BIO 2016-75327-R) and the Generalitat de Catalunya (XRB and 2017SGR-998). IRB Barcelona is the recipient of a Severo Ochoa Award of Excellence from MINECO (Government of Spain).

Institutional Review Board Statement: Not applicable.

Informed Consent Statement: Not applicable.

Data Availability Statement: Not applicable.

Acknowledgments: The authors acknowledge the support of the IRB Advanced Microscopy Core Facility, Mass Spectrometry Core Facility of IRB Barcelona, and Electronic Microscopy Facility from Centres Científics i Tecnològics Universitat de Barcelona.

Conflicts of Interest: The authors report no conflict of interest in this work.

\section{References}

1. Callaghan, C.; Peralta, D.; Liu, J.; Mandava, S.H.; Maddox, M.; Dash, S.; Tarr, M.A.; Lee, B.R. Combined Treatment of Tyrosine Kinase Inhibitor-Labeled Gold Nanorod Encapsulated Albumin with Laser Thermal Ablation in a Renal Cell Carcinoma Model. J. Pharm. Sci. 2016, 105, 284-292. [CrossRef]

2. $\quad$ Popp, M.K.; Oubou, I.; Shepherd, C.; Nager, Z.; Anderson, C.; Pagliaro, L. Photothermal Therapy Using Gold Nanorods and NearInfrared Light in a Murine Melanoma Model Increases Survival and Decreases Tumor Volume. J. Nanomater. 2014, $2014,450670$. [CrossRef]

3. Song, X.; Liang, C.; Gong, H.; Chen, Q.; Wang, C.; Liu, Z. Photosensitizer-Conjugated Albumin-Polypyrrole Nanoparticles for Imaging-Guided in Vivo Photodynamic/Photothermal Therapy. Small 2015, 11, 3932-3941. [CrossRef] [PubMed]

4. Yeo, E.L.L.; Cheah, J.U.J.; Neo, D.J.H.; Goh, W.I.; Kanchanawong, P.; Soo, K.C.; Thong, P.S.P.; Kah, J.C.Y. Exploiting the protein corona around gold nanorods for low-dose combined photothermal and photodynamic therapy. J. Mater. Chem. B 2017, 5, 254-268. [CrossRef]

5. Bayda, S.; Adeel, M.; Tuccinardi, T.; Cordani, M.; Rizzolio, F. The history of nanoscience and nanotechnology: From chemicalphysical applications to nanomedicine. Molecules 2020, 25, 112. [CrossRef]

6. Huang, H.; Lovell, J.F. Advanced Functional Nanomaterials for Theranostics. Adv. Funct. Mater. Theranostics 2017, $27,1603524$. [CrossRef]

7. Han, J.; Zhao, D.; Li, D.; Wang, X.; Jin, Z.; Zhao, K. Polymer-based nanomaterials and applications for vaccines and drugs. Polymers 2018, 10, 31. [CrossRef]

8. Aguilar, Z.P. Types of Nanomaterials and Corresponding Methods of Synthesis. In Nanomaterials for Medical Applications; Elsevier: Amsterdam, The Netherlands, 2013; pp. 33-82; ISBN 9780123850898.

9. Klebowski, B.; Depciuch, J.; Parlinska-Wojtan, M.; Baran, J. Applications of Noble Metal-Based Nanoparticles in Medicine. Int. J. Mol. Sci. 2018, 19, 4031. [CrossRef]

10. Vetterlein, C.; Vásquez, R.; Bolaños, K.; Acosta, G.A.; Guzman, F.; Albericio, F.; Celis, F.; Campos, M.; Kogan, M.J.; Araya, E. Exploring the influence of Diels-Alder linker length on photothermal molecule release from gold nanorods. Colloids Surf. B Biointerfaces 2018, 166, 323-329. [CrossRef]

11. Inostroza-Riquelme, M.; Vivanco, A.; Lara, P.; Guerrero, S.; Salas-Huenuleo, E.; Chamorro, A.; Leyton, L.; Bolaños, K.; Araya, E.; Quest, A.; et al. Encapsulation of Gold Nanostructures and Oil-in-Water Nanocarriers in Microgels with Biomedical Potential. Molecules 2018, 23, 1208. [CrossRef] 
12. An, Y.H.; Lee, J.; Son, D.U.; Kang, D.H.; Park, M.J.; Cho, K.W.; Kim, S.; Kim, S.H.; Ko, J.; Jang, M.H.; et al. Facilitated Transdermal Drug Delivery Using Nanocarriers-Embedded Electroconductive Hydrogel Coupled with Reverse ElectrodialysisDriven Iontophoresis. ACS Nano 2020, 14, 4523-4535. [CrossRef] [PubMed]

13. Lin, W.; Ma, G.; Yuan, Z.; Qian, H.; Xu, L.; Sidransky, E.; Chen, S. Development of Zwitterionic Polypeptide Nanoformulation with High Doxorubicin Loading Content for Targeted Drug Delivery. Langmuir 2019, 35, 1273-1283. [CrossRef] [PubMed]

14. Esteban-Fernández de Ávila, B.; Lopez-Ramirez, M.A.; Mundaca-Uribe, R.; Wei, X.; Ramírez-Herrera, D.E.; Karshalev, E.; Nguyen, B.; Fang, R.H.; Zhang, L.; Wang, J. Multicompartment Tubular Micromotors Toward Enhanced Localized Active Delivery. Adv. Mater. 2020, 32, 1-10. [CrossRef] [PubMed]

15. Pérez-Hernández, M.; Del Pino, P.; Mitchell, S.G.; Moros, M.; Stepien, G.; Pelaz, B.; Parak, W.J.; Gálvez, E.M.; Pardo, J.; De La Fuente, J.M. Dissecting the molecular mechanism of apoptosis during photothermal therapy using gold nanoprisms. ACS Nano 2015, 9, 52-61. [CrossRef]

16. Fazio, B.; D’Andrea, C.; Foti, A.; Messina, E.; Irrera, A.; Donato, M.G.; Villari, V.; Micali, N.; Maragò, O.M.; Gucciardi, P.G. SERS detection of Biomolecules at Physiological $\mathrm{pH}$ via aggregation of Gold Nanorods mediated by Optical Forces and Plasmonic Heating. Sci. Rep. 2016, 6, 1-13. [CrossRef]

17. Kelly, K.L.; Coronado, E.; Zhao, L.L.; Schatz, G.C. The Optical Properties of Metal Nanoparticles: The Influence of Size, Shape, and Dielectric Environment. J. Phys. Chem. B 2003, 107, 668-677. [CrossRef]

18. Mezni, A.; Dammak, T.; Fkiri, A.; Mlayah, A.; Abid, Y.; Smiri, L.S. Photochemistry at the surface of gold nanoprisms from surface-enhanced raman scattering blinking. J. Phys. Chem. C 2014, 118, 17956-17967. [CrossRef]

19. Santos, N.C.; Domingues, M.M.; Felício, M.R.; Gonçalves, S.; Carvalho, P.M. Application of Light Scattering Techniques to Nanoparticle Characterization and Development. Front. Chem. 2018, 6, 1-17. [CrossRef]

20. Liu, H.; Pierre-Pierre, N.; Huo, Q. Dynamic light scattering for gold nanorod size characterization and study of nanorod-protein interactions. Gold Bull. 2012, 45, 187-195. [CrossRef]

21. Sasidharan, S.; Bahadur, D.; Srivastava, R. Albumin stabilized gold nanostars: A biocompatible nanoplatform for SERS, CT imaging and photothermal therapy of cancer. RSC Adv. 2016, 6, 84025-84034. [CrossRef]

22. Bai, X.; Wang, Y.; Song, Z.; Feng, Y.; Chen, Y.; Zhang, D.; Feng, L. The basic properties of gold nanoparticles and their applications in tumor diagnosis and treatment. Int. J. Mol. Sci. 2020, 21, 2480. [CrossRef]

23. Khandelia, R.; Bhandari, S.; Pan, U.N.; Ghosh, S.S.; Chattopadhyay, A. Gold Nanocluster Embedded Albumin Nanoparticles for Two-Photon Imaging of Cancer Cells Accompanying Drug Delivery. Small 2015, 11, 4075-4081. [CrossRef]

24. Gonçalves, A.S.C.; Rodrigues, C.F.; Moreira, A.F.; Correia, I.J. Strategies to improve the photothermal capacity of gold-based nanomedicines. Acta Biomater. 2020, 116, 105-137. [CrossRef] [PubMed]

25. De Matteis, V.; Rizzello, L. Noble Metals and Soft Bio-Inspired Nanoparticles in Retinal Diseases Treatment: A Perspective. Cells 2020, 9, 679. [CrossRef]

26. Okoampah, E.; Mao, Y.; Yang, S.; Sun, S.; Zhou, C. Gold nanoparticles-biomembrane interactions: From fundamental to simulation. Colloids Surf. B Biointerfaces 2020, 196, 111312. [CrossRef]

27. Link, S.; El-sayed, M.A. Shape and size dependence of radiative, non-radiative and photothermal properties of gold nanocrystals. Int. Rev. Phys. Chem. 2000, 19, 409-453. [CrossRef]

28. Pelaz, B.; Grazu, V.; Ibarra, A.; Magen, C.; Del Pino, P.; De La Fuente, J.M. Tailoring the synthesis and heating ability of gold nanoprisms for bioapplications. Langmuir 2012, 28, 8965-8970. [CrossRef] [PubMed]

29. Alfranca, G.; Artiga, Á.; Stepien, G.; Moros, M.; Mitchell, S.G.; De La Fuente, J.M. Gold nanoprism-nanorod face off: Comparing the heating efficiency, cellular internalization and thermoablation capacity. Nanomedicine 2016, 11, 2903-2916. [CrossRef] [PubMed]

30. Wang, L.; Li, J.; Pan, J.; Jiang, X.; Ji, Y.; Li, Y.; Qu, Y.; Zhao, Y.; Wu, X.; Chen, C. Revealing the binding structure of the protein corona on gold nanorods using synchrotron radiation-based techniques: Understanding the reduced damage in cell membranes. J. Am. Chem. Soc. 2013, 135, 17359-17368. [CrossRef] [PubMed]

31. Alkilany, A.M.; Nagaria, P.K.; Hexel, C.R.; Shaw, T.J.; Murphy, C.J.; Wyatt, M.D. Cellular uptake and cytotoxicity of gold nanorods: Molecular origin of cytotoxicity and surface effects. Small 2009, 5, 701-708. [CrossRef]

32. Parab, H.J.; Chen, H.M.; Lai, T.C.; Huang, J.H.; Chen, P.H.; Liu, R.S.; Hsiao, M.; Chen, C.H.; Tsai, D.P.; Hwu, Y.K. Biosensing, cytotoxicity, and cellular uptake studies of surface-modified gold nanorods. J. Phys. Chem. C 2009, 113, 7574-7578. [CrossRef]

33. Koryakina, I.; Kuznetsova, D.S.; Zuev, D.A.; Milichko, V.A.; Timin, A.S.; Zyuzin, M.V. Optically Responsive Delivery Platforms: From the Design Considerations to Biomedical Applications. Nanophotonics 2020, 9, 39-74. [CrossRef]

34. Bhushan, B.; Khanadeev, V.; Khlebtsov, B.; Khlebtsov, N.; Gopinath, P. Impact of albumin based approaches in nanomedicine: Imaging, targeting and drug delivery. Adv. Colloid Interface Sci. 2017, 246, 13-39. [CrossRef]

35. Min, Y.; Caster, J.M.; Eblan, M.J.; Wang, A.Z. Clinical Translation of Nanomedicine. Chem. Rev. 2015, 115, 11147-11190. [CrossRef]

36. Bolaños, K.; Celis, F.; Garrido, C.; Campos, M.; Guzmán, F.; Kogan, M.J.; Araya, E. Adsorption of bovine serum albumin on gold nanoprisms: Interaction and effect of NIR irradiation on protein corona. J. Mater. Chem. B 2020, 8, 8644-8657. [CrossRef] [PubMed]

37. Loureiro, A.; Azoia, N.G.; Gomes, A.C.; Cavaco-Paulo, A. Albumin-Based Nanodevices as Drug Carriers. Curr. Pharm. Des. 2016, 22, 1371-1390. [CrossRef] 
38. Lee, E.S.; Youn, Y.S. Albumin-based potential drugs: Focus on half-life extension and nanoparticle preparation. J. Pharm. Investig. 2016, 46, 305-315. [CrossRef]

39. Bolaños, K.; Kogan, M.J.; Araya, E. Capping gold nanoparticles with albumin to improve their biomedical properties. Int. J. Nanomed. 2019, 14, 6387-6406. [CrossRef]

40. Ding, C.; Xu, Y.; Zhao, Y.; Zhong, H.; Luo, X. Fabrication of BSA@AuNC-Based Nanostructures for Cell Fluoresce Imaging and Target Drug Delivery. ACS Appl. Mater. Interfaces 2018, 10, 8947-8954. [CrossRef] [PubMed]

41. Zu, L.; Liu, L.; Qin, Y.; Liu, H.; Yang, H. Multifunctional BSA-Au nanostars for photoacoustic imaging and X-ray computed tomography. Nanomed. Nanotechnol. Biol. Med. 2016, 12, 1805-1813. [CrossRef] [PubMed]

42. Rahdar, S.; Rahdar, A.; Ahmadi, S.; Trant, J.F. Adsorption of bovine serum albumin (BSA) by bare magnetite nanoparticles with surface oxidative impurities that prevent aggregation. Can. J. Chem. 2019, 97, 577-583. [CrossRef]

43. Shanwar, S.; Liang, L.; Nechaev, A.V.; Bausheva, D.K.; Balalaeva, I.V.; Vodeneev, V.A.; Roy, I.; Zvyagin, A.V.; Guryev, E.L. Controlled Formation of a Protein Corona Composed ofDenatured BSA on Upconversion Nanoparticles ImprovesTheir Colloidal Stability. Pharamceutics 2021, 14, 1657.

44. Lillo, C.R.; Calienni, M.N.; Rivas, B.; Prieto, M.J.; Rodriguez, D.; Tuninetti, J.; Toledo, P.; Alonso, V.; Moya, S.; Gonzalez, M.C.; et al. BSA-capped gold nanoclusters as potential theragnostic for skin diseases: Photoactivation, skin penetration, in vitro and in vivo toxicity. Mater. Sci. Eng. C 2020, 112, 110891. [CrossRef]

45. Sabbarwal, S.; Dubey, A.K.; Pandey, M.; Kumar, M. Synthesis of Biocompatible, BSA capped Fluorescent CaCO3 Pre-Nucleation Nanoclusters for Cell Imaging Applications. J. Mater. Chem. B 2020, 8, 5729-5744. [CrossRef] [PubMed]

46. Bros, M.; Nuhn, L.; Simon, J.; Moll, L.; Mailänder, V.; Landfester, K.; Grabbe, S. The protein corona as a confounding variable of nanoparticle-mediated targeted vaccine delivery. Front. Immunol. 2018, 9, 1-10. [CrossRef]

47. Falahati, M.; Attar, F.; Sharifi, M.; Haertlé, T.; Berret, J.; Khan, R.H.; Saboury, A.A. A health concern regarding the protein corona, aggregation and disaggregation. Biochim. Biophys. Acta-Gen. Subj. 2019, 1863, 971-991. [CrossRef] [PubMed]

48. Francia, V.; Yang, K.; Deville, S.; Reker-Smit, C.; Nelissen, I.; Salvati, A. Corona Composition Can Affect the Mechanisms Cells Use to Internalize Nanoparticles. ACS Nano 2019, 13, 11107-11121. [CrossRef] [PubMed]

49. Bode, S.A.; Timmermans, S.B.P.E.; Eising, S.; Van Gemert, S.P.W.; Bonger, K.M.; Löwik, D.W.P.M. Click to enter: Activation of oligo-arginine cell-penetrating peptides by bioorthogonal tetrazine ligations. Chem. Sci. 2019, 10, 701-705. [CrossRef]

50. Åmand, H.L.; Rydberg, H.A.; Fornander, L.H.; Lincoln, P.; Nordén, B.; Esbjörner, E.K. Cell surface binding and uptake of arginineand lysine-rich penetratin peptides in absence and presence of proteoglycans. Biochim. Biophys. Acta-Biomembr. 2012, 1818, 2669-2678. [CrossRef]

51. Allolio, C.; Magarkar, A.; Jurkiewicz, P.; Baxová, K.; Javanainen, M.; Mason, P.E.; Šachl, R.; Cebecauer, M.; Hof, M.; Horinek, D.; et al. Arginine-rich cell-penetrating peptides induce membrane multilamellarity and subsequently enter via formation of a fusion pore. Proc. Natl. Acad. Sci. USA 2018, 115, 11923-11928. [CrossRef] [PubMed]

52. Zhao, P.; Li, F.; Huang, Y. Nanotechnology-Based Targeted Drug Delivery Systems and Drug Resistance in Colorectal Cancer; Elsevier Inc.: Amsterdam, The Netherlands, 2020; ISBN 9780128199374.

53. Pan, Z.; Kang, X.; Zeng, Y.; Zhang, W.; Peng, H.; Wang, J.; Huang, W.; Wang, H.; Shen, Y.; Huang, Y. A mannosylated PEI-CPP hybrid for TRAIL gene targeting delivery for colorectal cancer therapy. Polym. Chem. 2017, 8, 5275-5285. [CrossRef]

54. Garcia, J.; Fernández-Blanco, Á.; Teixidó, M.; Sánchez-Navarro, M.; Giralt, E. d-Polyarginine Lipopeptides as Intestinal Permeation Enhancers. ChemMedChem 2018, 13, 2045-2052. [CrossRef] [PubMed]

55. An, F.F.; Zhang, X.H. Strategies for preparing albumin-based nanoparticles for multifunctional bioimaging and drug delivery. Theranostics 2017, 7, 3667-3689. [CrossRef]

56. Palanikumar, L.; Al-Hosani, S.; Kalmouni, M.; Nguyen, V.P.; Ali, L.; Pasricha, R.; Barrera, F.N.; Magzoub, M. pH-responsive high stability polymeric nanoparticles for targeted delivery of anticancer therapeutics. Commun. Biol. 2020, 3, 1-17. [CrossRef] [PubMed]

57. Riveros, A.L.; Eggeling, C.; Riquelme, S.; Adura, C.; López-Iglesias, C.; Guzmán, F.; Araya, E.; Almada, M.; Juárez, J.; Valdez, M.A.; et al. Improving cell penetration of gold nanorods by using an amphipathic arginine rich peptide. Int. J. Nanomed. 2020, 15, 1837-1851. [CrossRef]

58. Garcia, J.; Fernández-Pradas, J.M.; Lladó, A.; Serra, P.; Zalvidea, D.; Kogan, M.; Giralt, E.; Sánchez-Navarro, M. The combined use of gold nanoparticles and infrared radiation enables cytosolic protein delivery. Chem. A Eur. J. 2020. [CrossRef]

59. Nakase, I.; Noguchi, K.; Aoki, A.; Takatani-Nakase, T.; Fujii, I.; Futaki, S. Arginine-rich cell-penetrating peptide-modified extracellular vesicles for active macropinocytosis induction and efficient intracellular delivery. Sci. Rep. 2017, 7, 1-12. [CrossRef] [PubMed]

60. Kamei, N.; Morishita, M.; Takayama, K. Importance of intermolecular interaction on the improvement of intestinal therapeutic peptide/protein absorption using cell-penetrating peptides. J. Control. Release 2009, 136, 179-186. [CrossRef]

61. Jiang, T.; Zhang, Z.; Zhang, Y.; Lv, H.; Zhou, J.; Li, C.; Hou, L.; Zhang, Q. Dual-functional liposomes based on pH-responsive cell-penetrating peptide and hyaluronic acid for tumor-targeted anticancer drug delivery. Biomaterials 2012, 33, 9246-9258. [CrossRef] [PubMed]

62. Ishikawa, M.; Biju, V. Luminescent Quantum Dots, Making Invisibles Visible in Bioimaging, 1st ed.; Elsevier Inc.: Amsterdam, The Netherlands, 2011; Volume 104, ISBN 9780124160200. 
63. Cassano, S.D.; Voliani, V. Photothermal effect by NIR-responsive excretable ultrasmall-in-nano architectures. Mater. Horiz. 2019, 6, 531-537. [CrossRef]

64. Scarabelli, L.; Sánchez-Iglesias, A.; Pérez-Juste, J.; Liz-Marzán, L.M. A “Tips and Tricks” Practical Guide to the Synthesis of Gold Nanorods. J. Phys. Chem. Lett. 2015, 6, 4270-4279. [CrossRef]

65. Melchionna, M.; Styan, K.; Marchesan, S. The unexpected advantages of using D-amino acids for peptide self-assembly into nanostructured hydrogels for medicine. Curr. Top. Med. Chem. 2016, 16, 2009-2018. [CrossRef]

66. Kelly, S.M.; Jess, T.J.; Price, N.C. How to study proteins by circular dichroism. Biochim. Biophys. Acta Proteins Proteom. 2005, 1751, 119-139. [CrossRef]

67. Grönbeck, H.; Curioni, A.; Andreoni, W. Thiols and disulfides on the Au(111) surface: The headgroup-gold interaction. J. Am. Chem. Soc. 2000, 122, 3839-3842. [CrossRef]

68. Maleki, M.S.; Moradi, O.; Tahmasebi, S. Adsorption of albumin by gold nanoparticles: Equilibrium and thermodynamics studies. Arab. J. Chem. 2017, 10, 491-502. [CrossRef]

69. de Oliveira Noman, L.; Sant'Ana, A.C. The control of the adsorption of bovine serum albumin on mercaptan-modified gold thin films investigated by SERS spectroscopy. Spectrochim. Acta Part. A Mol. Biomol. Spectrosc. 2018, 204, 119-124. [CrossRef]

70. Pramanik, S.; Banerjee, P.; Sarkar, A.; Bhattacharya, S.C. Size-dependent interaction of gold nanoparticles with transport protein: A spectroscopic study. J. Lumin. 2008, 128, 1969-1974. [CrossRef]

71. Treuel, L.; Malissek, M.; Gebauer, J.S.; Zellner, R. The influence of surface composition of nanoparticles on their interactions with serum albumin. ChemPhysChem 2010, 11, 3093-3099. [CrossRef] [PubMed]

72. del Caño, R.; Mateus, L.; Sánchez-Obrero, G.; Sevilla, J.M.; Madueño, R.; Blázquez, M.; Pineda, T. Hemoglobin bioconjugates with surface-protected gold nanoparticles in aqueous media: The stability depends on solution $\mathrm{pH}$ and protein properties. J. Colloid Interface Sci. 2017, 505, 1165-1171. [CrossRef] [PubMed]

73. Leopold, L.F.; Tódor, I.S.; Diaconeasa, Z.; Rugină, D.; Ştefancu, A.; Leopold, N.; Coman, C. Assessment of PEG and BSA-PEG gold nanoparticles cellular interaction. Colloids Surf. A Physicochem. Eng. Asp. 2017, 532, 70-76. [CrossRef]

74. Binaymotlagh, R.; Hadadzadeh, H.; Farrokhpour, H.; Haghighi, F.H.; Abyar, F.; Mirahmadi-Zare, S.Z. In situ generation of the gold nanoparticles-bovine serum albumin (AuNPs-BSA) bioconjugated system using pulsed-laser ablation (PLA). Mater. Chem. Phys. 2016, 177, 360-370. [CrossRef]

75. Alsamamra, H.; Hawwarin, I.; Sharkh, S.A.; Abuteir, M. Study the Interaction between Gold Nanoparticles and Bovine Serum Albumin: Spectroscopic Approach. J. Bioanal. Biomed. 2018, 10, 43-49. [CrossRef]

76. Vio, V.; Riveros, A.L.; Tapia-Bustos, A.; Lespay-Rebolledo, C.; Perez-Lobos, R.; Muñoz, L.; Pismante, P.; Morales, P.; Araya, E.; Hassan, N.; et al. Gold nanorods/siRNA complex administration for knockdown of PARP-1: A potential treatment for perinatal asphyxia. Int. J. Nanomed. 2018, 13, 6839-6854. [CrossRef] [PubMed]

77. Li, D.; Zhang, M.; Xu, F.; Chen, Y.; Chen, B.; Chang, Y.; Zhong, H.; Jin, H.; Huang, Y. Biomimetic albumin-modified gold nanorods for photothermo-chemotherapy and macrophage polarization modulation. Acta Pharm. Sin. B 2018, 8, 74-84. [CrossRef] [PubMed]

78. Kun, R.; Szekeres, M.; Dékány, I. Isothermal titration calorimetric studies of the $\mathrm{pH}$ induced conformational changes of bovine serum albumin. J. Therm. Anal. Calorim. 2009, 96, 1009-1017. [CrossRef]

79. Zhao, J.; Stenzel, M.H. Entry of nanoparticles into cells: The importance of nanoparticle properties. Polym. Chem. 2018, 9, 259-272. [CrossRef]

80. Wu, B.; Deng, S.; Zhang, S.; Jiang, J.; Han, B.; Li, Y. PH sensitive mesoporous nanohybrids with charge-reversal properties for anticancer drug delivery. RSC Adv. 2017, 7, 46045-46050. [CrossRef]

81. Jurašin, D.D.; Ćurlin, M.; Capjak, I.; Crnković, T.; Lovrić, M.; Babič, M.; Horák, D.; Vrček, I.V.; Gajović, S. Surface coating affects behavior of metallic nanoparticles in a biological environment. Beilstein J. Nanotechnol. 2016, 7, 246-262. [CrossRef] [PubMed]

82. Zhang, L.; Xia, K.; Bai, Y.Y.; Lu, Z.; Tang, Y.; Deng, Y.; Chen, J.; Qian, W.; Shen, H.; Zhang, Z.; et al. Synthesis of gold nanorods and their functionalization with bovine serum albumin for optical hyperthermia. J. Biomed. Nanotechnol. 2014, 10, 1440-1449. [CrossRef]

83. Wang, X.; Li, J.; Kawazoe, N.; Chen, G. Photothermal Ablation of Cancer Cells by Albumin-Modified Gold Nanorods and Activation of Dendritic Cells. Materials 2018, 12, 31. [CrossRef]

84. Zhou, B.; Song, J.; Wang, M.; Wang, X.; Wang, J.; Howard, E.W.; Zhou, F.; Qu, J.; Chen, W.R. BSA-bioinspired gold nanorods loaded with immunoadjuvant for the treatment of melanoma by combined photothermal therapy and immunotherapy. Nanoscale 2018, 10, 21640-21647. [CrossRef] [PubMed]

85. Adura, C.; Guerrero, S.; Salas, E.; Medel, L.; Riveros, A.; Mena, J.; Arbiol, J.; Albericio, F.; Giralt, E.; Kogan, M.J. Stable conjugates of peptides with gold nanorods for biomedical applications with reduced effects on cell viability. ACS Appl. Mater. Interfaces 2013, 5, 4076-4085. [CrossRef]

86. Charbgoo, F.; Nejabat, M.; Abnous, K.; Soltani, F.; Taghdisi, S.M.; Alibolandi, M.; Thomas Shier, W.; Steele, T.W.J.; Ramezani, M. Gold nanoparticle should understand protein corona for being a clinical nanomaterial. J. Control. Release 2018, 272, 39-53. [CrossRef]

87. Bao, C.; Beziere, N.; Del Pino, P.; Pelaz, B.; Estrada, G.; Tian, F.; Ntziachristos, V.; De La Fuente, J.M.; Cui, D. Gold nanoprisms as optoacoustic signal nanoamplifiers for in vivo bioimaging of gastrointestinal cancers. Small 2013, 9, 68-74. [CrossRef] [PubMed]

88. Ambrosone, A.; Del Pino, P.; Marchesano, V.; Parak, W.J.; De La Fuente, J.M.; Tortiglione, C. Gold nanoprisms for photothermal cell ablation in vivo. Nanomedicine 2014, 9, 1913-1922. [CrossRef] [PubMed]

89. Liu, M.; Li, Q.; Liang, L.; Li, J.; Wang, K.; Li, J.; Lv, M.; Chen, N.; Song, H.; Lee, J.; et al. Real-Time visualization of clustering and intracellular transport of gold nanoparticles by correlative imaging. Nat. Commun. 2017, 8, 1-10. [CrossRef] [PubMed] 